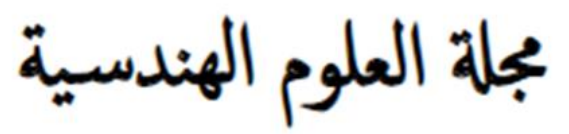

\title{
Application of Quality Assessment System in Sudanese Construction Industry
}

\author{
Yasir Mohamed Hassan Amin ${ }^{1}$, , Mohamed Abdulla Nugdalla Ahmedi' \\ 1 Resident Engineer, Murtada Maaz Consultancy Company, Obied Khatim Street, Khartoum, Sudan. \\ 2 Contract Engineer, Dam Implementation Unit, Nile Street, Khartoum, Sudan. \\ * Corresponding author: Yasir Mohamed Hassan Amin (e-mail: yasseramin 06@yahoo.com).
}

Article history: Received 31 March 2020, Received in revised form 4 November 2020, Accepted 11 November 2020

\begin{abstract}
Quality management is considered one of the most important obstacles facing the construction industry in Sudan. The application of a quality assessment system contributes to the development of quality in projects as it is possible to measure the quality in projects. This paper aims to introduce one of the quality assessment systems, which is the system followed and applied in the Singapore (CONQUAS). This system assesses quality based on structural, architectural, mechanical and electrical work. The paper also aims to study the factors affecting the application of the quality assessment system in Sudan. The study is carried out in the region of Khartoum. The study is focusing on the construction projects. The study is carried out by questionnaires and other literature review. The respondents are consultants and contractors. The data has been distributed and analyzed by using the Average Index. From the study it was found that CONQUAS standard is assessed the building based on workmanship standards by the assessors from the BCA on site using standard score sheets. The assessment is done throughout the construction process for structural, mechanical and electrical works, and from questionnaire results the main factors affect construction industry in Sudan is lack of standardization in Sudan. The author recommended that more study shall be conducted to identify factors affecting quality in Sudanese construction industry and how to improve the quality.
\end{abstract}

Keywords: CONQUAS, Quality, Quality assessment.

\section{INTRODUCTION}

Time, cost and quality considered as project constrain and the success of the project is depending mainly on these factors. However, for the majority of projects, the cost and time parameters are the main preoccupying factors (Rwelamila and Hall 1995) [1]. Quality has been a big issue in the construction industry. The decline in the level of quality in the construction industry is due to the most companies are unwilling to change and the construction industry has a number of parties each one of them play a role to ensure the quality of the product, any poor performance for one party affect the performance for another party.

Ho (1999) [2] defined building evaluation as

\section{'the systematic assessment of building} performance relative to defined objectives and requirements.' An effective quality assessment system should be able to detect and measure all types of defects and capture all aspects of construction quality that affect the performance of buildings. The quality assessment can be carried out by measuring the constructed works against workmanship standards and specifications. Such measurements have to be comprehensive, straightforward, consistent and effective. Furthermore, the assessments have to be carried out systematically and within reasonable cost and time frame (Council for Scientific and Industrial Research, 2005) [3].

Different quality assessment systems are being used in the world for the construction industry to 
increase satisfaction of residents and quality. These systems also determine the standards for construction.

\section{A. Problem Statement}

The absence of evaluation system and standards in construction industry is one of the key problems because systematic evaluation works to the benefit of all who use buildings or are otherwise involved in their creation and operation. Due to the absence of evaluation system, quality of buildings is not measured and it is not clear that whether occupants are satisfied with their product or not and if you cannot measure you cannot manage. Thus, a standard quality level in construction projects is not attained.

In the construction industry, factors such as change, customer demands, competitive pressure and cost affect an organization's ability to understand the client's requirements and meet first time, at minimum cost and high quality. Thus, it is vital to develop a quality management system that avoids any inefficiency that could result in poor quality of products and services being delivered to the customer; and which helps to improve quality and productivity by eliminating the causes of nonconformance to requirements in all activities.

\section{B. Aims and Objectives}

The aim of this study is to bring concept of quality assessment system in Sudanese construction industry. To attain this aim, the following objectives of the study are undertaken:

1. To identify how to assess the quality in construction project, according to CONQUAS. 2. To study the factors affecting application of CONQUAS.

\section{LITERATURE REVIEW}

\section{A. CONQUAS}

To enhance and promote quality construction in Singapore, the Building and Construction Authority (BCA) introduced the Construction Quality Assessment System (CONQUAS) in 1989 to evaluate the quality performance of building contractors in the public sector (Low,Kee and Leng, 1999) [4].
There are three objectives for CONQUAS (Singapore Building Construction Authority, 2005) [5]:

1) To have a standard quality assessment system for construction projects.

2) To make quality assessment objective by:

measuring constructed works against workmanship standards and specification.

using a sampling approach to suitably represent the whole project.

3) To enable quality assessment to be carried out systematically within reasonable cost and time.

The CONQUAS covers most aspects of the general building works. The assessment consists of three components (Singapore Building Construction Authority, 2005):

$>$ Structural works.

$>$ Architectural works.

> Mechanical and electrical works.

Each component is further divided into different items for assessment. However, the assessment excludes works such as piling, heavy foundation and sub-structure works which are heavily equipment based and called under separate contracts or subcontracts.

\section{B. Structural works}

The structural integrity of the building is of paramount importance as the costs of failure and repairs are very significant. The assessment of structural works comprises:

$>$ Site inspection of formwork, steel reinforcement, prefabricated components, etc. during construction. The assessment shall include structural steel and prestressed concrete if each constitutes more than $20 \%$ of the total structural cost. Precast elements are assessed if the precast concrete volume exceeds $20 \%$ of total structural concrete volume.

Laboratory testing of compressive strength of concrete and tensile strength of steel reinforcement.

$>$ Non-destructive testing of the uniformity and the cover of hardened concrete. 


\section{Architectural works}

Architectural works deal mainly with the finishes and components. This is the part where the quality and standard of workmanship are most visible. The assessment covers:

> Site inspection of internal finishes, roofs, external walls and external works at the completion stage of the building. Internal finishes include floors, internal walls, ceiling, doors, windows and components.

Material and functional tests such as on window water tightness, wet area water-tightness test and adhesion of internal wall tiles. There is also in process assessment on installation of waterproofing for internal wet areas.

\section{Mechanical and electrical works}

The quality of mechanical and electrical works is important in view of its increasingly high cost proportion and its impact on the performance of a building. The assessment covers electrical works, air-conditioning and mechanical ventilation works (ACMV), fire protection works, sanitary and plumbing works and the basic mechanical and electrical fittings. The stages of the assessment include:

> Site inspection of installed works before embedded/concealed. Such items include ACMV ductworks, electrical conduits, concealed pipes, etc.

$>$ Site inspection of final installed works such as the air handling unit (AHU), cooling tower, fire alarm control panel, etc.

> Performance tests on selected works such as the water pressure test, earthing test, dry riser test, etc.

The building is assessed primarily on workmanship standards by the assessors from the BCA on site using standard score sheets. The assessment is done throughout the construction process for structural, mechanical and electrical works and on the completed building for The scores from the assessments are then summed to provide the total CONQUAS score for the building being evaluated. The weightages for structural, architectural and mechanical-electrical works are allocated according to four categories of buildings as in figure 1

\begin{tabular}{|c|c|c|c|c|c|c|}
\hline \multirow[t]{2}{*}{ Components } & \multirow[b]{2}{*}{\begin{tabular}{|l|} 
CAT A \\
Commercial, \\
Industrial, \\
Institution, \\
Mixed \\
Development \\
\& others \\
\end{tabular}} & \multicolumn{2}{|l|}{ CAT B } & \multicolumn{2}{|l|}{ CATC } & \multirow{2}{*}{$\begin{array}{l}\text { CAT D } \\
\text { Landed } \\
\text { Housing }\end{array}$} \\
\hline & & $\begin{array}{l}\text { Commercial, } \\
\text { Industrial, } \\
\text { Institution, } \\
\text { Mixed } \\
\text { Development } \\
\text { \& others }\end{array}$ & $\begin{array}{l}\text { Private } \\
\text { Housing }\end{array}$ & $\begin{array}{l}\text { Public } \\
\text { Housing } \\
\text { (Sold } \\
\text { Flats) }\end{array}$ & $\begin{array}{l}\text { Public } \\
\text { Housing } \\
\text { (Rental } \\
\text { Flats) }\end{array}$ & \\
\hline $\begin{array}{l}\text { Structural } \\
\text { Works }\end{array}$ & $10 \%$ & $15 \%$ & $10 \%$ & $15 \%$ & $20 \%$ & $10 \%$ \\
\hline $\begin{array}{l}\text { Architectural } \\
\text { Works }\end{array}$ & $75 \%$ & $80 \%$ & $85 \%$ & $80 \%$ & $75 \%$ & $85 \%$ \\
\hline M\&E Works & $15 \%$ & $5 \%$ & $5 \%$ & $5 \%$ & $5 \%$ & $5 \%$ \\
\hline $\begin{array}{l}\text { CONQUAS } \\
\text { Score }\end{array}$ & $100 \%$ & $100 \%$ & $100 \%$ & $100 \%$ & $100 \%$ & $100 \%$ \\
\hline
\end{tabular}

Fig. 1. CONQUAS Building Categories and Weight System (Singapore BCA 2019) [6].

CONQUAS does not attempt to measure the quality of building design. It only assesses the extent to which the contractor has met the specifications and requirements of the designers (Low, 1993) [7].

Furthermore, as it is impossible to inspect every single component of a building because of time constraints; CONQUAS uses a sampling system for the assessment. The sampling system, which is mainly based on the gross floor area of the building, ensures that the assessment adequately represents the entire building. Selection of samples is based on drawings and location plans.

The scoring is done on the works that are inspected for the first time. Rectification and correction carried out after the assessment are not re-scored. The objective of this practice is to encourage contractors to do things right the first time. When an assessed item does not comply with the corresponding CONQUAS standards, it is considered failed and " $\mathrm{X}$ " is noted in the assessment form. Likewise, " $\sqrt{ }$ " is given for an item meeting the standards. "-" indicates that the item is not applicable. The score is computed based on the number of " $\sqrt{ }$ " over the total number of items assessed.

There are clear advantages and disadvantages for CONQUAS model (Minchin and Smith, 2001) [8], the advantage are as follows:

1. A well-defined measurement that ensure measurements among various projects to be 
compared on an equal basis.

2. The independent third party is involved in the project and views quality and test results without knowledge of interacting factors.

3. By modifying the bid amount rather than the prequalification, the contractor is being rewarded for consistently providing above the targeted level of quality.

Disadvantages of the CONQUAS are as follow:

1. Does not consider the effectiveness of the contractor's safety or management systems.

2 . The cost of supporting a third party process must be considered in weighting the total costs.

\section{RESEARCH METHODOLOGY}

\section{A. Data collection}

The data has been collected by using online questionnaire (survey monkey) As shown in table this questionnaire delivered to 80 responded and the respondents are the consultants, contractors and project managers.

\section{B. Average Index}

The data was studied and analyzed using Microsoft Excel for Microsoft Professional Windows 7. The analysis of the data from the received feedback from the questionnaire gives average index calculation. This index was calculated

Average Index Formula:

Average Index $(\mathrm{AI})=(\Sigma \mu \mathrm{X} n) / \mathrm{N}$

Where:

$\mu=$ Weighting given to each factor by respondents (1 to 5);

$\mathrm{n}=$ Frequency of the respondents; and

$\mathrm{N}=$ Total number of respondents.

\section{TABLE 1: RATING SCALE OF AVERAGE INDEX}

\begin{tabular}{cl}
\hline \hline Average Index & Rating scale \\
\hline $1.00 \leq$ Average Index $<1.50$ & Strongly Disagree \\
$1.50 \leq$ Average Index $<2.50$ & Disagree \\
$2.50 \leq$ Average Index $<3.50$ & Slightly Agree \\
$3.50 \leq$ Average Index $<4.50$ & Agree \\
$4.50 \leq$ Average Index $\leq 5.0$ & Strongly Agree \\
\hline \hline
\end{tabular}

\section{DATA ANALYSIS}

This study has focused on the factor affecting applying of quality assessment system in
Sudanese construction industry. Questionnaire was design online by survey monkey software and the data collected were analyzed to achieve the objectives of this projects. Therefore, the following results were found in relation to the selected objectives for the study.

TABLE 2: DETAILED OF ADMINISTERED QUESTIONNAIRE

\begin{tabular}{lll}
\hline \hline QUESTIONNAIRES & QUANTITY & PERCENTAGE $\%$ \\
\hline Delivered & 80 & \\
Responded & 36 & $45 \%$ \\
No Response & 44 & $55 \%$ \\
Total & & $100 \%$ \\
\hline \hline
\end{tabular}

TABLE 3: LEVEL OF EXPERIENCE FOR RESPONDENT

\begin{tabular}{ccll}
\hline \hline $\begin{array}{c}\text { LEVEL } \\
\text { EXPERIENCE }\end{array}$ & OF & FREQUENCY & PERCENTAGE $(\%)$ \\
\hline $\begin{array}{l}\text { LESS THAN } \\
\text { YEARS }\end{array}$ & 5 & 8 & $22.22 \%$ \\
5-10 YEARS & & 16 & $44.44 \%$ \\
10-15 YEARS & & 7 & $19.44 \%$ \\
$\begin{array}{l}\text { MORE THAN } \\
\text { YEARS }\end{array}$ & 15 & 5 & $13.89 \%$ \\
\hline \hline
\end{tabular}

TABLE 4: FACTORS AFFECTING APPLYING OF QUALITY ASSESSMENT SYSTEM

\begin{tabular}{|c|c|c|c|c|c|c|c|}
\hline \multirow{2}{*}{ No. } & \multirow{2}{*}{ Factors } & \multicolumn{5}{|c|}{ Scale } & \multirow{2}{*}{$(\mathrm{AI})$} \\
\hline & & 1 & 2 & 3 & 4 & 5 & \\
\hline 1 & $\begin{array}{l}\text { lack of standardization in } \\
\text { Sudan }\end{array}$ & 3 & 1 & 2 & 13 & 17 & 4.11 \\
\hline 2 & $\begin{array}{l}\text { Competitive pressure } \\
\text { and cost affect an } \\
\text { organization's ability to } \\
\text { understand the client's } \\
\text { requirements and meet } \\
\text { first time, at minimum } \\
\text { cost and high quality }\end{array}$ & 1 & 3 & 12 & 16 & 4 & 3.53 \\
\hline 3 & customer demand & 3 & 8 & 7 & 13 & 5 & 3.25 \\
\hline 4 & Level of understanding & 2 & 4 & 8 & 15 & 7 & 3.58 \\
\hline 5 & $\begin{array}{l}\text { ability to change the } \\
\text { culture }\end{array}$ & 1 & 8 & 5 & 14 & 8 & 3.56 \\
\hline
\end{tabular}

As shown in table 4 the respondents agreed factors mentioned above and lack of standardization is the most critical one.

TABLE 5: SECTOR WITH MORE PROBLEM IN QUALITY

\begin{tabular}{lll}
\hline \hline Sector & Response & $\begin{array}{l}\text { Number of } \\
\text { respondent }\end{array}$ \\
\hline Public & $72.22 \%$ & 26 \\
Private & $27.78 \%$ & 10 \\
\hline \hline
\end{tabular}

As shown in table above most of respondent faced quality problem in public projects, so there is a need to focus more in this sector

TABLE 6: METHOD FOR QUALITY ASSESSMENT

\begin{tabular}{lll}
\hline \hline Method & Response & $\begin{array}{l}\text { Number of } \\
\text { respondent }\end{array}$ \\
\hline Experience of Engineer & $25 \%$ & 9
\end{tabular}




\begin{tabular}{lll}
$\begin{array}{l}\text { Applying quality } \\
\text { assessment }\end{array}$ & $41.67 \%$ & 15 \\
$\begin{array}{l}\text { Applying of quality } \\
\text { management }\end{array}$ & $33.33 \%$ & 12 \\
\hline
\end{tabular}

As shown in table 6, $41.67 \%$ of respondent agree with applying of quality assessment system to increase the quality of construction projects and accordingly applying of these system is must.

\section{CONCLUSION}

A.Objective 1: To identify how to assess the quality in construction project, according to CONQUAS The above objective of the project has been achieved through the literature review, from the study, it was found that

CONQUAS: The short form of the Construction Quality Assessment System is CONQUAS, it was introduced by the Building and Construction Authority (BCA). The Building and Construction Authority (BCA) is developed by the Singapore government, the main objective of CONQUAS is assessing the quality of construction works to ensure the quality of the project fulfill the quality standard.

The building is assessed primarily on workmanship standards by the assessors from the BCA on site using standard score sheets. The assessment is done throughout the construction process for structural, mechanical and electrical works and on the completed building for architectural works.

B. Objective 2: To study the factors affecting application of CONQUAS. The second objective of the study have been achieved by analyzing the questionnaire. From the study the main factors affecting applying of quality assessment system are:

1. Lack of standardization in Sudan.

2. Competitive pressure and cost affect an organization's ability to understand the client's requirements and meet first time, at minimum cost and high quality.

3. Customer demand.

4. Level of understanding.

5. Ability to change the culture.
All respondents are agree with factors mentioned in the survey

\section{RECOMMENDATION}

1. More study shall be conducted for the factor affecting applying of quality assessment system.

2. More research shall be conducted to present quality assessment suitable for Sudanese construction projects.

3. Training shall be provided to contractor and consultant company and to be sponsored by government.

Applying of quality assessment system together with other quality management system such as six sigma.

\section{REFERENCES}

[1] Rwelamila, P.D. and Hall, K.A. (1995) Total systems intervention: an integrated approach to time, cost and quality management, Construction Management and Economics, 13, 235-41.

[2] HO, D.C.W. (1999) Preferences on office Quality Attributes Proceedings from PRRES Conference 26-31 January Kuala Lumpur Malaysia.

[3] Council for Scientific and Industrial Research web-site, retrieved July 12, 2005, http://www.csir.co.za/akani

[4] LOW, P.S, KEE T.B. and A.A.A. LENG (1999) Effectiveness of ISO 9000 in Raising Construction Quality Standards: Some Empirical Evidence Using CONQUAS Scores, Structural Survey, Vol.17, No.2, pp.89-108, MCB University Press

[5] Singapore Building Construction Authority web-site, CONQUAS Manual, retrieved February 07, 2005, http://www.bca.gov.sg/Professionals/IQUAS/others/CON21.pd

[6] Singapore Building Construction Authority web-site, CONQUAS Manual, retrieved 2019, NINTH Edition http://www.bca.gov.sg/Professionals/IQUAS/others/CON21.pd $\mathrm{f}$

[7] LOW, P.S. (1993) The Conceptual Relationships between Construction Quality and Economic Development, International Journal of Quality and Reliability Management, Vol.10, No.2, pp.18-30

[8]

[9] MINCHIN R.E. and G.R. SMITH (2001) Quality-Based Contractor Rating Model for Qualification and Bidding Purposes, Journal of Management in Engineering, Vol.21, pp.38-43, ASCE

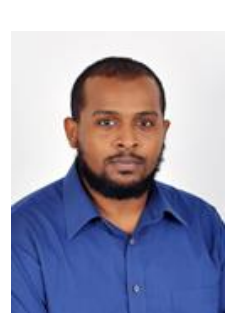

Yasir Mohamed. Saudi Arabia /1988. Civil Engineer. Master of Engineering, Construction Management, University of Technology Malaysia, Johor, Malaysia, 2016. BSc of Civil Engineering, University of Khartoum, Khartoum, Sudan, 2011

$\mathrm{He}$ is working as Resident Engineer at Murtada Maaz Consultancy since 2012, Khartoum, Sudan. He has previous publication in the second conference of civil engineering titled On Site Quality Assessment of Building Projects in Khartoum, Sudan, 2018, 
University of Khartoum.

Mr. Yasir has membership in Project Management Institute, USA as Local Chapter Since February 2018 and certified Project Management Professional (PMP), Mr. Yasir is also member of a Sudanese Engineering Society.

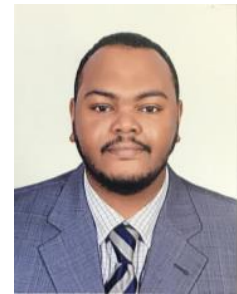

Mohamed Abdulla Nugdalla, Khartoum 1989 BSc of Civil Engineering, University of Khartoum, Khartoum, Sudan, 2011 - MEng in Construction Management, University of Technology Malaysia, Johor, Malaysia, 2016

$\mathrm{He}$ is civil engineer currently working in the dam implementation unit, Khartoum Sudan since 2013,

$\mathrm{He}$ is one of engineers that have been contributed in the construction of Dam Complex of Upper Atbara Project. Mr. Nugdalla is registered in the Sudanese Engineering Council as a Specialist Engineer. He is also a member of the American society of civil engineering, Sudanese Engineering Society in University of Khartoum. Mr. Nugdalla has obtained Dr. Said Ahmed Eljacks Prize for the Best Academic Performance in Soil Mechanics and Foundation Engineering in the 5th Year at BSc and also he is certified Project Management Professional (PMP) from the Project Management Institute, USA. 